\title{
Chemical Composition of Cell-wall Polysaccharide of Rough Mutants of Salmonella typhimurium
}

\author{
By T. HOLME \\ Department of Bacteriology, Karolinska Institutet, Stockholm \\ A. A. LINDBERG \\ Department of Bacteriology, National Bacteriological Laboratory, Stockholm \\ P. J. GAREGG AND T. ONN \\ Department of Organic Chemistry, University of Stockholm \\ (Accepted for publication 17 November 1967)
}

\begin{abstract}
SUMMARY
Quantitative analyses of monosaccharide constituents of the cell-wall polysaccharide of the smooth form and rough mutants of Salmonella typhimurium were made by gas-liquid chromatography of glycitol acetates produced from acid hydrolysates of phenol + water extracts of cell-wall preparations. The presence, in varying amounts, of sugars characteristic of the S-specific repeating unit was detected in all rough mutants investigated. Definite conclusions about the core structure of the different rough mutants could not be drawn by using only the basis of the monosaccharide composition of the cell-wall polysaccharide. Ribose was found in the cell-wall polysaccharide of the smooth form in small amounts.
\end{abstract}

\section{INTRODUCTION}

The essential structural features of the cell-wall polysaccharide in Salmonella have been elucidated by immunochemical and chemical methods (Kauffmann, Lüderitz, Stierlin \& Westphal, I960; Kauffmann, Krüger, Lüderitz \& Westphal, I96I ; Beckmann, Subbaiah \& Stocker, I964; Osborn et al. 1964; Lüderitz et al. 1965; Nikaido, Naide \& Mäkelä, 1966). The polysaccharide molecule is composed of a core to which long side chains containing repeating units are attached (Fig. I). The repeating units contain the specific structures of the $O$ antigen determinants. The chemical composition of some of these determinants has been completely clarified. (For a review see Lüderitz, Staub \& Westphal, 1966.) Rare monosaccharides which have not been found in the core structure are often present in the repeating unit. The core region is believed to be similar in all salmonellas. A side chain containing glucose, galactose and $N$-acetylglucosamine is linked to an internal backbone composed of Lipid A, 2-keto-3-deoxyoctulosonic, ethanolamine, phosphate and heptose. The biosynthesis of this side chain appears to involve a sequential transfer of the monosaccharides in the form of nucleotide sugars to the backbone by transferase systems (Osborn, 1966). Studies of the core have been made possible through the use of rough mutants defective in different biosynthetic steps. The designation of these mutants is based on both the chemical composition of the cell-wall polysaccharide- 
$\mathrm{Ra}, \mathrm{Rb}, \mathrm{Rc}, \mathrm{Rd}$, Re according to Lüderitz, Staub \& Westphal (I966) and the serological specificity, RI-RII (Beckmann, Lüderitz \& Westphal, I964; Lüderitz, Beckmann \& Westphal, 1964).

Studies on the monosaccharide composition, by using thin-layer chromatography, of the cell-wall polysaccharide of rough mutants of Salmonella typhimurium, selected by the use of phages, revealed the unexpected presence of mannose (Holme, I965). The application of gas-liquid chromatography for the separation of monosaccharides as described by Sawardeker, Sloneker \& Jeanes (I965) offered a more sensitive method for such studies. The aim of the investigations is to study the structure and function of the receptors for different bacteriophages. The present report deals with the chemical composition of the cell-wall polysaccharide of smooth and rough strains of $S$. typhimurium and $S$. minnesota.

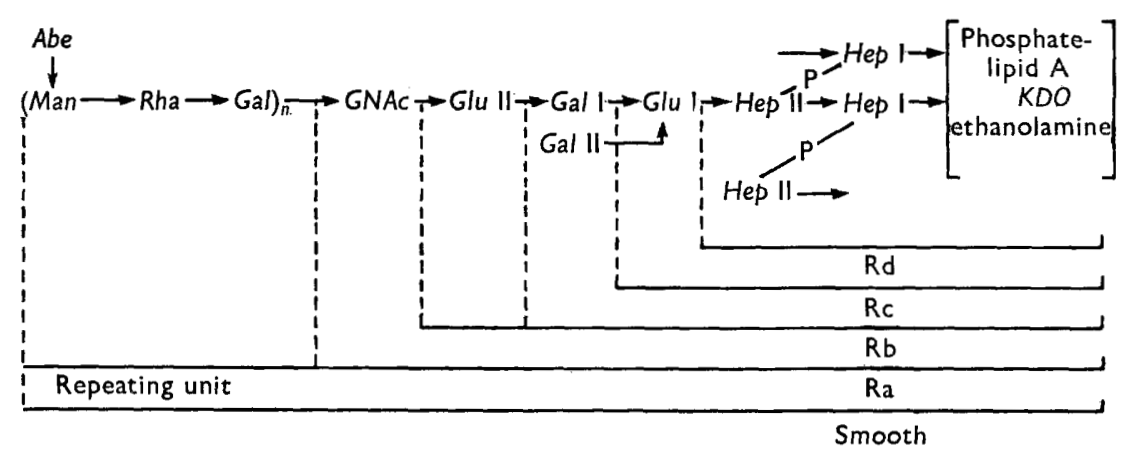

Fig. I. Main features of the proposed structure of the cell-wall lipopolysaccharide of Salmonella typhimurium. The abbreviations used are: $K D O, 2-k e t o-3-d e o x y-D-m a n n o-$ octulosonic acid; Hep, L-glycero-D-manno-heptose; Glu, D-glucose; Gal, D-galactose; GNAc, $N$-acetyl-D-glucosamine; Rha, L-rhamnose; Man, D-mannose; $A b e$, abequose $(3,6-$ dideoxy-D-xylo-hexose).

\section{METHODS}

Bacterial strains. Salmonella typhimurium $395 \mathrm{MS}$ was the parent strain of the isolated rough mutants. The mutant strains derived from $S$. typhimurium LT 2-TV I60, TVI6I, TVI63, TVI66, TV208, TV225, TV 226 and TV227-were obtained from Dr B. A. D. Stocker (Lister Institute of Preventive Medicine, London). The mutants TVII9 and TVI48 were obtained from Dr M. Raynaud (Institut Pasteur, Paris). Salmonella minnesota $\mathrm{S} 99$ and the mutants R60 and R345 derived from this strain were supplied by Dr O. Lüderitz (Max Planck-Institute für Immunbiologie, Freiburg).

Phage stocks. The Salmonella phages Felix O-I (Felix \& Callow, 1943) and 4 (Lilleengen, 1948) were propagated by the soft agar layer method (Adams, I959).

Isolation of mutants. For the isolation of phage-resistant mutants, the bacteria were plated with an appropriate dilution of the phage stocks using the soft top-layer agar technique (Adams, I959). The initial bacterial number on each plate was approximately $10^{8}$. The input multiplicity of phage was 10 . After incubation at $37^{\circ}$ for $18 \mathrm{hr}$ five colonies were picked from each plate and transferred to nutrient agar plates. Daily transfer was done until no free phage could be detected by spot test against the parent strain. No adsorption of the phages FO-I or 4 to the isolated mutants could be demonstrated. 
Another series of mutants was isolated by picking rough-looking colonies from broth cultures of the strain Salmonella typhimurium 395MS. The mutant 395MRo was isolated from a I-week-old nutrient broth culture. The mutants 395MR I-R4 were prepared as follows. An $18 \mathrm{hr}$ culture of the parent strain was subjected to ultraviolet (u.v.) irradiation so as to obtain approximately $0.1 \%$ survival. Ten $0.05 \mathrm{ml}$. portions from the u.v.-treated suspension were each inoculated into $10 \mathrm{ml}$. nutrient broth. From these cultures rough mutants were isolated after incubation at $37^{\circ}$ for 2 weeks. Mutants with different antigenic patterns in the gel precipitin test were chosen for further study. The mutants used are listed in Table $\mathrm{I}$.

Virulence and protection tests. The methods used have been described previously (Holme \& Edebo, 196r, Edebo \& Holme, 1965). In the virulence tests $20 \mathrm{~g}$. mice were used.

Preparation of cell walls. Bacteria were grown in a medium of the following composition (g.): glucose, 5 ; tryptone (Difco), I0; yeast extract (Difco), $5 ; \mathrm{K}_{2} \mathrm{HPO}_{4}, 7$; $\mathrm{KH}_{2} \mathrm{PO}_{4}, 3 ; \mathrm{NaCl}, 0.5$; in $1000 \mathrm{ml}$. distilled water.

\section{Table I. Rough mutants of Salmonella typhimurium 395MS}

Method of isolation
Broth culture
U.v., broth culture
Phage FO-I
Phage 4

Method of isolation

$\begin{array}{lll}\text { 395 MR o } & & \\ \text { 395 MR I } & \text { 395 MR } 2 & \text { 395 MR 3 395 MR 4 } \\ \text { 395 MR 5 } & \text { 395 MR 6 } & \text { 395 MR Io } \\ \text { 395 MR } 7 & \text { 395 MR } 8 & \text { 395 MR 9 }\end{array}$

Cultivation was in 51 . indented Erlenmeyer flasks; the culture volume in each flask was 21 . The flasks were placed on a rotary shaker and incubated for $18 \mathrm{hr}$ at $37^{\circ}$. The yield varied between $\mathrm{I} \cdot 5$ and $2 \cdot 5 \mathrm{~g}$. dry wt bacteria/l. culture. Cell walls were prepared by disintegrating the centrifuged organisms in the frozen state in the X-press (Edebo, I960). Initial separation of walls from cell debris was effected by centrifugation at $10,000 \mathrm{~g}$ for $20 \mathrm{~min}$. in an IEC-PR 2 refrigerated centrifuge at $+4^{\circ}$. The cell walls collected as a loosely packed layer on the pellet surface; they were washed off by careful rinsing. The wall preparation was then washed twice in $0.1 \mathrm{M}$-phosphate buffer $(\mathrm{pH} 7)$, once in $\mathrm{M}$-sodium chloride and once in distilled water. The washing procedure was done in the cold. The cell walls were then suspended in distilled water. No intact bacteria could be observed when the preparations were examined by phase microscopy.

Extraction of lipopolysaccharide. Lipopolysaccharide was extracted from the cell walls by the phenol + water procedure of Westphal, Lüderitz \& Bister (1952). A scanning spectrophotometer (Beckmann $\mathrm{Dk}_{2}$ ) was used for the detection of ultraviolet absorbing substances in the preparations.

Estimation of hexosamines. Hexosamine was estimated according to Gatt \& Berman (1966) on polysaccharides obtained by hydrolysis in acetic acid of lipopolysaccharides according to Sutherland, Lüderitz \& Westphal (1965).

Gas-chromatographic analysis of the carbohydrate composition of cell-wall lipopolysaccharide hydrolysates. The analysis was based on the method described by Sawardeker et al. (1965). The dialysed cell-wall extracts contained between 0.6 and $4.6 \mathrm{mg}$. polysaccharide $/ \mathrm{ml}$. by the anthrone method and expressed as glucose (Whistler \& Wolfrom, 1962). For the analysis a volume containing approximately $2 \mathrm{mg}$. was taken. The extracts were hydrolysed in $0.5 \mathrm{~N}$-sulphuric acid at $100^{\circ}$ overnight. 
The acid was removed by Dowex 3 (free base) and the solution concentrated under reduced pressure to about $\mathrm{I} \mathrm{ml}$. The mixtures of aldoses were reduced to the corresponding alditols with sodium borohydride overnight. Excess borohydride was destroyed by Dowex $50 \mathrm{~W}-\mathrm{X} 8$ and boric acid removed as methyl borate by several distillations with methanol under reduced pressure. The syrups were dried by distillation under reduced pressure with benzene, and then fully acetylated with acetic anhydride + pyridine ( $\mathrm{I}: \mathrm{I} \mathrm{v} / \mathrm{v})$ at $100^{\circ}$ for $10-15 \mathrm{~min}$. Excess of acetic anhydride was removed by

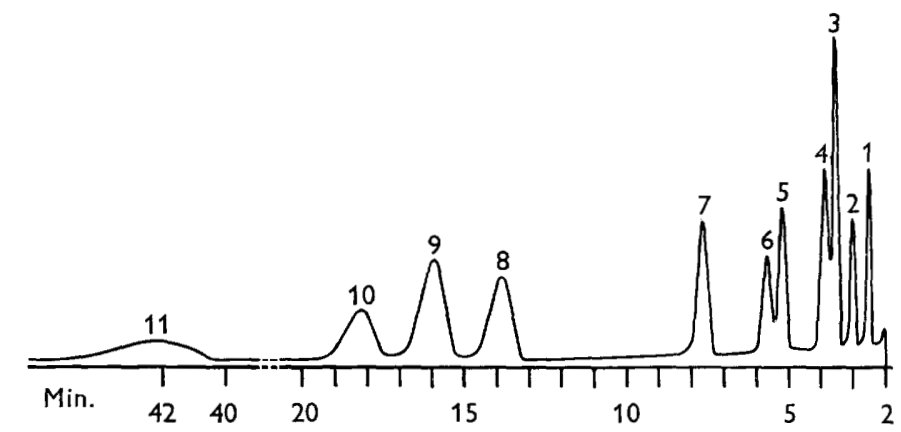

Fig. 2. Chromatogram of alditol acetates of reference sugars. Column: $3 \%$ ECNSS-M on Gas-Chrom Q. Injector temperature $270^{\circ}$, column temperature $170^{\circ}$, detector temperature $240^{\circ}$. Flow: $30 \mathrm{ml} . \mathrm{N}_{2} / \mathrm{min}$ I, Tyvelose (3,6-didenxy-D-arabino-hexose); 2 , abequose (3,6dideoxy-D-xylo-hexose); 3 , rhamnose; 4, fucose; 5 , ribose; 6, arabinose; 7 , xylose; 8 , mannose; 9, galactose; 10, glucose; I I, L-glycero-D-manno-heptose.

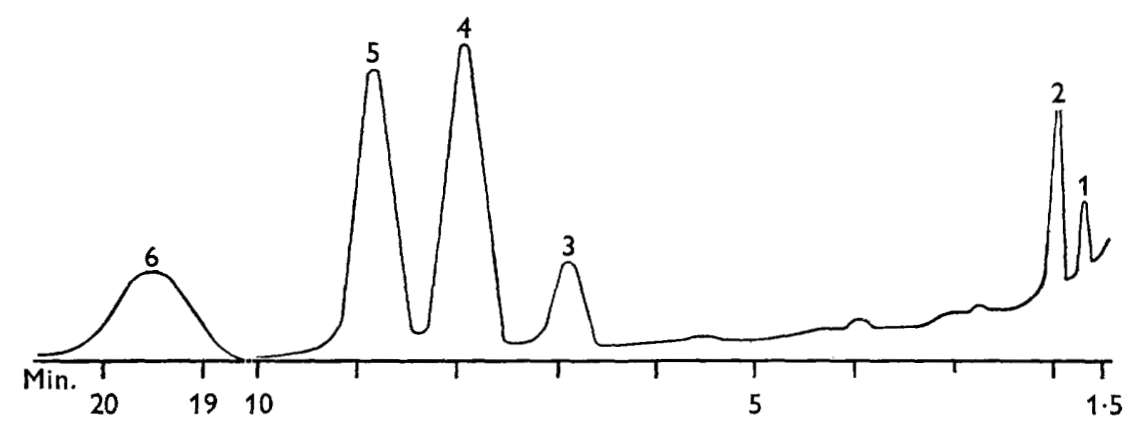

Fig. 3. Chromatogram of alditol acetates of sugars from Salmonella typhimurium TV225 cell-wall polysaccharide. Column: $3 \%$ ECNSS-M on Gas-Chrom Q. Injector temperature $270^{\circ}$, column temperature $180^{\circ}$, detector temperature $240^{\circ}$. Flow: $32 \mathrm{ml}$. $\mathrm{N}_{2} / \mathrm{min}$. I, Abequose; 2 , rhamnose; 3 , mannose; 4 , galactose; 5 , glucose; 6 , heptose.

adding water and the resulting solution concentrated to dryness. The resulting mixture of fully acetylated alditol acetates was dissolved in chloroform and analysed by gas-liquid chromatography. The solutions ( $\mu \mathrm{l}$.) were injected on to an ECNSS (polyester-silicone) glass column fitted in a Perkin-Elmer Model 80I gas chromatograph. The injection temperature was $265-270^{\circ}$, column temperature $170-175^{\circ}$, detector

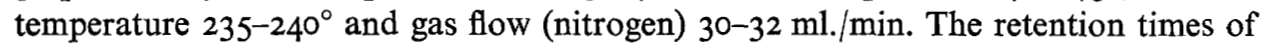
the various acetates were identical to those of authentic polyacetates of each of the various glycitols. The glycitols were further identified by adding reference materials 
to the mixtures. Complete separation of the glycitol acetates was obtained (Figs. 2, 3). The response of the flame-ionization detector to all the glycitol acetates was found to be linear and was determined for each one. The relative peak areas were determined for the mixtures from the various lipopolysaccharides and molecular ratios for the constituent sugars calculated from these, after suitable correction for the different response of the detector to the various glycitol acetates. The method was tested by subjecting known mixtures of the various sugars to the above procedure. The ratios found differed from those calculated by not more than \pm 3 mole $\%$. Losses of the most volatile of the glycitol acetates, that derived from abequose, during the workingup of the acetylation mixture, were found to be negligible.

\section{RESULTS}

\section{Growth characteristics of the mutants}

All the mutants developed rough colonies after incubation for $48 \mathrm{hr}$ on nutrient agar. On galactose Endo agar all strains except R9 showed positive fermentation reaction. The mutant $\mathrm{R} 9$ developed smooth colonies on this medium. This mutant was also unable to grow on minimal medium with galactose as the sole carbon source. All the mutants grew on minimal media with glucose as the sole carbon source.

\section{Biological characteristics}

The parent strain was highly virulent for mice. All mice in a group of ro died within 7 days after inoculation of approximately 50 viable bacteria/mouse. For virulence tests of the rough mutant strains, doses of $2-8 \times 10^{5}$ viable bacteria were inoculated into groups of Io mice. All strains of Salmonella typhimurium except R 4 listed in Table 1 were tested. Strain R 4 was lost after the chemical analyses had been made, and no virulence tests could be done. No deaths were recorded.

Protection tests were made using suspension of heat-killed cells of the smooth form and the mutants $\mathrm{RO}, \mathrm{R} 5, \mathrm{R} 6, \mathrm{R} 7, \mathrm{R} 8, \mathrm{R} 9$ and $\mathrm{R} \mathrm{IO}_{\mathrm{O}}$ as immunizing agents. PD 50 of the smooth form was $6 \times 10^{-5} \mathrm{mg}$. (dry weight). No protection was obtained in groups of mice treated with $0.3 \mathrm{mg}$. of cells of the rough mutants.

\section{Chemical composition of cell-wall polysaccharides}

The data from the gas chromatographic analysis of the polysaccharide hydrolysates and the separate determination of glucosamine are given in Table 2. The quantities of the individual sugars are given in mole $\%$ of the detected sugars to facilitate the comparison of ratios between polysaccharides from different strains.

Various peaks obtained from contaminating materials were always observed, particularly in the region of the peaks for pentitol and deoxyhexitol acetates. The alditols in this region were therefore always particularly carefully identified by adding reference glycitols, thereby obtaining 'mixed' chromatograms. The assignments were further confirmed by employing a mass spectrometer connected to the gas chromatograph. The mass spectra of abequitol, rhamnitol, pentitols and hexitols were clearly different. The peaks of the glycitol acetates obtained from the hydrolysates gave mass spectra identical to those of the corresponding reference substances.

In the region of the hexitol peaks, including that given by mannitol acetate, inter- 
fering non-carbohydrate material was absent. Between the peaks of glucitol and heptitol an unidentified peak was regularly found. The presence of mannose in some of the hydrolysates was confirmed by paper and thin-layer chromatography. The detection of rhamnose and abequose was facilitated by the use of gas chromatography, the sensitivity of which is much greater than that of paper chromatography.

Table 2. Chemical composition of cell-wall polysaccharides from Salmonella typhimurium $395 M S$ and rough mutants, rough mutants of S. typhimurium LT2 (TV strains) and $S$. minnesota $S 99$ and rough mutants $R 60$ and $R 345$

Figures for all monosaccharides except glucosamine represent mole $\%$ of detected sugars. Glucosamine is given in \% of polysaccharide by the anthrone method. ND = not detected.

\begin{tabular}{|c|c|c|c|c|c|c|c|c|}
\hline Mutant & Hep & Glu & Gal & Man & Rha & Abe & $\begin{array}{c}\text { GN } \\
\% \text { of } \\
\text { polysacch. }\end{array}$ & $\begin{array}{l}\text { Proposed } \\
\text { chemical } \\
\text { designation }\end{array}$ \\
\hline $395 \mathrm{MS}$ & $<I$ & 30 & 22 & $2 I$ & 18 & 9 & $3 \cdot 6$ & XIV \\
\hline $395 \mathrm{MRO}$ & 32 & $3 I$ & 33 & 3 & $\mathbf{I}$ & $<\mathrm{I}$ & $16 \cdot 7$ & $\mathbf{R a}$ \\
\hline $395 \mathrm{MR}$ I & 40 & 2 I & $3 I$ & 4 & 3 & I & $I \cdot 4$ & $\mathbf{R b}$ \\
\hline 395 MR 2 & 38 & 22 & 37 & 2 & I & $<$ I & $2 \cdot 6$ & $\mathrm{Ra}$ \\
\hline $395 \mathrm{MR} 3$ & 46 & 22 & 25 & 4 & 2 & I & 5.0 & $\mathrm{Ra}$ \\
\hline $395 \mathrm{MR} 4$ & 30 & 30 & $3 I$ & 5 & 3 & I & 5.0 & $\mathrm{Ra}$ \\
\hline 395 MR 5 & 23 & 19 & 26 & 17 & II & 4 & $I \cdot 8$ & $\mathrm{Rb}$ \\
\hline $395 \mathrm{MR} 6$ & 27 & 19 & 28 & 12 & 8 & 6 & $1 \cdot 0$ & $\mathrm{Rb}$ \\
\hline 395 MR 7 & 43 & 27 & 19 & 7 & 3 & I & $2 \cdot 1$ & $\mathrm{Rb}$ \\
\hline $395 \mathrm{MR} 8$ & 50 & 22 & 20 & 5 & 2 & $<$ I & 0.8 & $\mathrm{Rb}$ \\
\hline 395 MR 9 & $4 I$ & 46 & 5 & 4 & 2 & 2 & 0.7 & Rc \\
\hline 395 MR IO & 67 & 3 & 9 & I4 & 5 & 2 & $I \cdot 3$ & Rd \\
\hline TV 160 & 32 & 22 & 32 & 7 & 5 & 2 & $I \cdot I$ & $\mathrm{Rb}$ \\
\hline TV I6I & 34 & 19 & 32 & 9 & 4 & 2 & 0.6 & $\mathrm{Rb}$ \\
\hline TV 163 & 27 & 26 & 28 & 9 & 7 & 3 & $3 \cdot 3$ & $\mathbf{R a}$ \\
\hline TV 208 & 7 & 9 & 34 & 24 & I7 & 9 & $5 \cdot 2$ & $\mathrm{Ra}$ \\
\hline TV 225 & 30 & 26 & $3 I$ & 7 & 4 & 2 & $2 \cdot 7$ & $\mathrm{Ra}$ \\
\hline s 99 & 23 & 23 & 54 & ND & ND & ND & - & II \\
\hline R 60 & 26 & 36 & 38 & ND & ND & ND & - & $\mathrm{Ra}$ \\
\hline R 345 & 30 & 20 & 50 & ND & ND & ND & - & $\mathrm{Rb}$ \\
\hline
\end{tabular}

Hep $=$ heptose, $\mathrm{Glu}=$ glucose, $\mathrm{Gal}=$ galactose, $\mathrm{Man}=$ mannose, $\mathrm{Rha}=$ rhamnose, Abe $=$ abequose, $\mathrm{GN}=$ glucosamine.

The parent strain, 395 Ms, showed an extremely low value of heptose, which indicates that the core region is only a minor component of the $\mathbf{S}$ polysaccharide. The same tendency was apparent for strain TV 208. One mutant, R IO, with the proposed chemotype $\mathrm{Rd}$, displayed a heptose value of 67 . The remaining mutants showed values between 23 and 50 mole \%. Glucose was significantly lower in the mutants R Io and TV 208 than in the other strains. Galactose was low in strains R9 and R IO. The galactose-non-fermentor $\mathrm{R} 9$ is of chemotype Rc.

The glucosamine values for the proposed $\mathrm{Ra}$ mutants fell between 2.6 and $16 \cdot 7$. Mutants belonging to chemotypes $\mathrm{Rb}, \mathrm{Rc}$ and $\mathrm{Rd}$ had glucosamine values between 0.6 and $2 . \mathrm{I}$. The quantities of glucosamine in the Salmonella minnesota strains were not determined, since the specific structure contains galactosamine, and the method of analysis did not distinguish between these hexosamines. Ribose was found in small amounts, about $I \%$, in the cell-wall polysaccharide of the smooth form of $S$. typhimurium but not in the smooth form of $S$. minnesota. It was also present in small amounts in some of the mutants representing all chemotypes. The ribose values 
were not incorporated in Table $\mathrm{I}$ because of the uncertainty of the origin of this sugar, when it was present in very small amounts.

The S-specific sugars mannose, rhamnose and abequose were found in appreciable amounts in all the rough mutants. The strains TV 208, R 5 and R 6 contained these sugars in especially high quantities. Mannose was always present in greater amounts than rhamnose and abequose.

\section{DISCUSSION}

Various methods for the analysis of the monosaccharide composition of lipopolysaccharides have been used. Analysis by paper chromatography is complicated by the number of components present. This makes the use of several solvent systems necessary. The use of enzymic methods on the other hand makes the combination of these various analyses into relative ratios for the monosaccharides somewhat uncertain.

The method used in the present work is essentially that described by Sawardeker et al. (1965) in which hydrolysates containing the monosaccharide mixture are converted into the corresponding glycitol acetates. This mixture is readily separated and analysed by gas chromatography. The method is rapid, relatively simple and has the advantage of giving a simultaneous determination of the components. In the procedure used here the glucosamine is, however, removed from the mixture.

The presence of mannose, rhamnose and abequose in all the rough mutants of Salmonella typhimurium raised the question whether the strains were unstable and frequently reverted to the wild type. The conclusion that this was not the case was drawn from the following facts. (I) The mutants from $S$. typhimurium 395 MS have been kept in the laboratory for 5 years without any signs of reversion, only rough colonies being observed when the strains were plated on nutrient agar. (2) The antigenic pattern in gel precipitin tests has been constant during this time (unpublished). (3) Vaccines prepared from the mutant strains did not confer protection in mice against challenge with viable $S$. typhimurium 395MS. (4) The mutants behaved as typical rough strains in serological tests and phage typing (Lindberg \& Holme, I968). (5) All mutants were avirulent. The dose used in these tests was approximately $5 \times 10^{5}$ viable bacteria. Since the smooth bacteria are highly virulent $(L D 50<50)$, revertants would have been detected in a proportion of less than $I$ in $10^{4}$ bacteria. Such a low proportion of smooth bacteria could not have any influence on the results of the chemical and immunological investigations.

Several explanations can be given for the presence of mannose, rhamnose and abequose in the rough mutants. The enzymic block which can lead to roughness may result in defective synthesis of one or more of the component monosaccharides, or it may result in a defective transfer of the sugars to the lipopolysaccharide core. A partial synthesis of the S-specific polysaccharide would result if the enzymic block was not complete or if secondary synthetic pathways could be used in the synthesis. Gemski \& Stocker (1967) attributed the capacity of some rough mutants to maintain the propagation of the smooth specific phage $\mathrm{P}_{22}$ and the evocation of $\mathrm{P}_{22}$ transductants from such strains to incomplete deficiencies (leaky mutations). Kalckar, Laursen \& Rapin (I966) attributed the presence of small amounts of galactose in an UDP-galactose-4-epimerase negative mutant of Escherichia coli $\mathrm{K}$ I 2 to the possibility that galactose was synthetised by an alternative pathway. The small epimerase 
activity detected was considered insufficient to explain the amount of galactose detected in the lipopolysaccharide.

The parent smooth strain and some of the rough mutants of Salmonella typhimurium displayed small amounts of ribose. The presence of $I-4 \%$ ribose in the lipopolysaccharide of RII-mutants of different Salmonella was reported by Lüderitz et al. (I966). Lipopolysaccharides from Salmonella T I strains, which lack the S-specific side chains, contain large amounts of ribose and galactose. Genetic analysis showed that $\mathrm{T}$ I strains have active genes ( $r f t_{\mathrm{I}}$ gene) for producing $\mathrm{T}$ I specificity which are lacking or inactive in the smooth strain (Sarvas, 1968). Recombination experiments between $\mathrm{T}$ I strains and well-defined rough mutants indicated that the $r f t I$ gene was only expressed when the complete core was present. Ribose should then be found only in mutants of chemotype Ra and in smooth strains if the rft I gene is not completely repressed. The determination of this sugar is, however, complicated by the possibility of cytoplasmic contamination of the lipopolysaccharide preparations. The lipopolysaccharide extracted from cell walls of the smooth strain $S$. typhimurium $395 \mathrm{MS}$ did not show any absorption at $260 \mathrm{~m} \mu$ which indicates that the ribose (approximately $\mathrm{I} \%$ ) detected in this extract was not derived from contaminating ribonucleic acid. No ribose was found in the extracts of $S$. minnesota R60, which is of chemotype $\mathrm{Ra}$. This finding needs further investigation, since it was reported by Lüderitz et al. (1966) that this mutant incorporates small amounts of ribose in its lipopolysaccharide.

Ribitol was found by Lilly (I962) in extracts from isolated cell walls from Escherichia coli 26-26. Since the gas chromatographic method was based on the separation of glycitols, no differentiation could be made between ribose and ribitol. By using paper chromatography it could be shown that the hydrolysates of cell walls from Salmonella typhimurium 395 Ms contained small amounts of ribose as compared to galactose, mannose and rhamnose.

It was not possible to designate the mutants to the groups $\mathrm{Ra}, \mathrm{Rb}$, etc., using only the basis of the chemical composition of the cell-wall polysaccharide (Table 2). The presence of haptenic polysaccharide containing S-specific determinants in supernatant fluids from phenol + water extracts from whole bacteria (L I-fraction of Beckmann, Subbaiah \& Stocker, 1964), which was easily detected by the gel precipitin reaction (unpublished), could not be used as a criterion for the $\mathrm{Rb}$ mutants, since two of the known Ra mutants, TVI63 and 225, both displayed this antigen. The proposed chemical grouping of Table 2 was therefore based on phage patterns and immunological investigations (see Lindberg \& Holme, 1968), in addition to cultural and chemical data. A difference in the glucosamine content between the Ra mutants, on the one hand, and $\mathrm{Rb}, \mathrm{Rc}$ and Rd mutants, on the other, was recorded, but the amounts detected did not make a sharp distinction possible. The presence of large amounts of glucosamine in Lipid A complicates an accurate determination of this amino sugar in the polysaccharide. After the removal of the lipid by acid hydrolysis, small amounts of contaminating glucosamine might remain in the preparation. Part of the glucosamine in some of the mutants was, however, probably associated with the presence of the S-specific sugars.

The fact that the rough mutants selected for resistance against the phages FO-I or 4 were of chemotype $\mathrm{Rb}, \mathrm{Rc}$ and $\mathrm{Rd}$, supports the assumption that the receptor sites for these phages are associated with the Ra structure (Lindberg, I967). Mutants 
selected for rough colony type appear to be predominantly of the chemotype $\mathrm{Ra}$.

The mutant R9, which was a galactose-non-fermenter, showed characteristics of being deficient in the enzyme UDP-gal-4-epimerase. The presence of S-specific sugars in this mutant raised the question whether the culture medium used contained galactose. When analysed by the gas chromatographic method described above no traces of galactose, mannose, ribose, rhamnose or abequose could be detected in the tryptone or the yeast extract. Strain R IO, which was the only mutant showing a low glucose content of its cell-wall polysaccharide, was believed to be deficient in the glucosyl-I-transferase system (Osborn et al. 1964), since it showed normal growth characteristics on a glucose-salts medium.

A further class of mutants of Salmonella was described by Naide et al. (1965). These mutants were termed semi-rough and displayed characteristics intermediate between the smooth and the rough forms with respect to cultural and serological behaviour. The lipopolysaccharide of these strains all contained the S-specific sugars but in smaller amounts than found in the wild-type strain. The results of phage typing and serological investigations presented by Lindberg \& Holme (I968) disclose the possibility that the mutants used in the present investigation belong to the semi-rough group.

We are grateful to colleagues mentioned above for the generous supply of bacterial strains. Our thanks are due to Dr O. Lüderitz for gifts of abequose, Dr N. O. K. Richtmeyer for heptose and Dr G. Bagdian for tyvelose; also to Professor G. Widmark for spectrometry facilities and Professor B. Lindberg for valuable discussions. The skilled technical assistance of Miss Berit Lindholm and Mrs Maud Bröms is gratefully acknowledged.

This work was supported by grants nos. B67-40X-656-02 and B67-40X-786-02 from the Swedish Medical Research Council and from Emil och Wera Cornells Stiftelse.

\section{REFERENCES}

Adams, M. H. (1959). Bacteriophages. New York: Interscience Publishers, Inc.

Beckmann, I., Lüderitz, O. \& Westphal, O. (1964). Zur Immunchemie der somatischen Antigene von Enterobacteriaceae. IX. Serologische Typisierung von Salmonella-R-Antigenen. Biochem. Z. 339, 401 .

Beckmann, I., Subbaiah, T. V. \& Stocker, B. A. D. (I964). Rough mutants of Salmonella typhimurium. 2. Serological and chemical investigations. Nature, Lond. 201, I 299.

EDEBo, L. (1960). A new press for the disruption of microorganisms and other cells. J. biochem. microbiol. Technol. Engng 2, 453.

Edebo, L. \& Holme, T. (I965). Preparation of biologically active fractions of Salmonella typhimurium. 3. Extraction of immunogenic components. Acta path. microbiol. scand. 63, 228.

Felix, A. \& Callow, B. R. (1943). Typing of paratyphoid B bacilli by means of Vi bacteriophage. Br. med. J. ii, 127.

GATT, R. \& BERMAN, E. R. (1966). A rapid procedure for the estimation of amino sugars on a micro scale. Analyt. Biochem. I5, 167.

Gemski, P., Jun. \& StockeR, B. A. D. (1967). Transduction by bacteriophage P 22 in nonsmooth mutants of Salmonella typhimurium. J. Bact. 93, 1588.

Holme, T. (1965). Antigens of phage-resistant mutants of Salmonella typhimurium. Acta path. microbiol. scand. 64, 14I.

Holme, T. \& Edebo, L. (I96I). Preparations of biologically active fractions of Salmonella typhimurium. I. Cultivation methods. Acta path. microbiol. scand. 5I, I64.

Kalckar, H., M. Laursen, P. \& RaPin, A. M. C. (1966). Inactivation of phage C 2 I by various preparations from lipopolysaccharide of E. coli K-I 2. Proc. natn. Acad. Sci. U.S.A. 56, 1852. 
KaUfFMANN, F., KRÜGer, L., LÜderitz, O. \& WeStPhal, O. (I961). Zur Immunchemie der O-Antigene von Enterobacteriaceae. VI. Vergleich der Zuckerbausteine von Polysacchariden aus Salmonella S-und R-formen. Zentbl. Bakt. ParasitKde (Abt. I, Orig.) r82, 57.

Kauffmann, F., Lüderitz, O., Stierlin, H. \& WestPhal, O. (1960). Zur Immunchemie der O-Antigene von Enterobacteriaceae. I. Analyse der Zuckerbausteine von Salmonella O-Antigen. Zentbl. Bakt. ParasitKde (Abt. I, Orig.) r78, 442.

LilleEngen, K. (1948). Typing of Salmonella typhimurium by means of bacteriophage. Acta path. microbiol. scand. suppl. 77.

LiLly, M. D. (I962). Cell-wall precursors in Escherichia coli 26-26. J. gen. Microbiol. 28, ii.

LiNDbERG, A. A. (1967). Studies of a receptor for Felix O-I phage in Salmonella minnesota. J. gen. Microbiol. 48, 225.

LindBerg, A. A. \& Holme, T. (I968). Immunochemical studies on cell-wall polysaccharide of rough mutants of Salmonella typhimurium. J. gen. Microbiol. 52, 55 .

LÜDERITZ, O., BECKMANN, I. \& WeSTPHAL, O. (1964). Zur Immunchemie der somatischen Antigene von Enterobacteriaceae. X. R-spezifische Strukturen in Salmonella-O-Antigenen. Biochem. $Z$. 339, 4 I6.

LÜDERITZ, O., Staub, A. M. \& WestPhal, O. (1966). Immunochemistry of O and R antigens of Salmonella and related Enterobacteriaceae. Bact. Rev. 30, 192.

Lüderitz, O., Risse, H. J., Schulte-Holthausen, H., Strominger, J. L., Sutherland, I. W. \& WestPhaL, O. (1965). Biochemical studies of the smooth-rough mutation in Salmonella minnesota. J. Bact. 89, 343.

Lüderitz, O., Galanos, C., Risse, H. J., Ruschmann, E., Schlecht, S., Smidt, G., SchulteHolthausen, H., Wheat, R., Westphal, O. \& Schlosshardt, J. (I966). Structural relationships of Salmonella $\mathrm{O}$ and $\mathrm{R}$ antigens. Ann. N.Y. Acad. Sci. 133, 349,

Naide, Y. ,Nikaido, H., Mäkelä, P. H., Wilkinson, R. G. \& Stocker, B. A. D. (1965). Semirough strains of Salmonella. Proc. natn. Acad. Sci. U.S.A. 53, 147.

Nikaido, H., NAIDE, Y. \& MÄkelä, P. H. (I966). Biosynthesis of O-antigenic polysaccharides in Salmonella. Ann. N.Y. Acad. Sci. 133, 299.

OsBorn, M. J. (I966). Biosynthesis and structure of the core region of the lipopolysaccharide in Salmonella typhimurium. Ann. N.Y. Acad. Sci. r33, 375.

Osborn, M. J., Rosen, S. M., Rothfield, L., Zeleznick, L. D. \& Horecker, B. L. (1964). Lipopolysaccharides of the gram-negative cell wall. Science, N.Y. 145, 783.

Sarvas, M. (1968). Inheritance of Salmonella T I antigen. Ann. Med. exp. Fenn. 45 (in the Press).

SAWARDEker, J. S., Sloneker, J. H. \& JeANES, A. (I965). Quantitative determination of monosaccharides as their alditol acetates by gas liquid chromatography. Analyt. Chem. 37, I602.

SUTHERLAND, I. W., LÜDERITZ, O. \& WestPhal, O. (1965). Studies on the structure of lipopolysaccharides of Salmonella minnesota and Salmonella typhimurium R strains. Biochem. J. 96, 439.

WestPhal, O., Lüderitz, O. \& Bister, F. (I952). Über die Extraktion von Bakterien mit Phenol/ Wasser. $Z$. Naturforsch. $7 b, 148$.

Whistler, R. L. \& Wolfrom, M. L. (1962). Methods in Carbohydrate Chemistry. I. Analysis and Preparation of Sugars. New York and London: Academic Press. 